\title{
The Social Construction of "Religion" and Its Limits: A Critical Reading of Timothy Fitzgerald
}

\author{
Kevin Schilbrack \\ Department of Philosophy and Religion, 226-A Stillwell, \\ Western Carolina University, Cullowhee, NC 28723, USA \\ kschilbrack@email.wcu.edu
}

\begin{abstract}
Several theorists argue that the concept of "religion" is not a cultural universal but rather emerged under particular historical and political conditions in the modern post-Reformation west. "Religion," they say, is a social construction. What are the implications of this view of the ontology of religion? My aim in this paper is to critically engage the arguments of Timothy Fitzgerald-a social constructionist about religion who combines, in my judgment, insight and confusion on the issue-in order to trace out the values and the limits of this approach.
\end{abstract}

Keywords

religion, social construction, deconstruction, ontology, Timothy Fitzgerald

\section{Introduction}

Several theorists argue that the concept of "religion" is not a cultural universal but rather emerged under particular historical and political conditions in the modern post-Reformation west. "Religion," they say, is a social construction. What are the implications of this view of the ontology of religion? My aim in this paper is to critically engage the arguments of Timothy Fitzgerald-a social constructionist about religion who combines, in my judgment, insight and confusion on the issue-in order to trace out the values and the limits of this approach.

Fitzgerald's project is to argue that "religion" is an ideologically motivated social construction. He argues that the view that there are religions around the world is not a discovery but instead the product of an expansionist Europe

1 Others who argue that "religion" is a modern western invention include Wilfred Cantwell Smith (1962), Jonathan Z. Smith (1998), Dubuisson (2003), Russell McCutcheon (2001), and Balagangadhara (1994). 
that sought a vocabulary for distinguishing its own modern, rational culture from those it sought to label backward and superstitious, and towards this end it invented and employed the label "secular" for itself and the label "religious" for its other. Fitzgerald's goal is to deconstruct "religion," to dissolve both the concept and the academic field of Religious Studies that emerged to manage it. ${ }^{2}$

My paper is a critique of that project. I agree that "religion" is a social construction. I will argue nevertheless that "religion" is descriptively and analytically useful, and it is useful because there really are religions that exist "out there" in the world. But I begin with an appreciation. On the following three points, each of which is central to his project, I judge that Fitzgerald is persuasive, and importantly so. ${ }^{3}$

The first and central aspect of Fitzgerald's position is his claim that the concept of "religion" is a social construction. Other cultures lack the concept: as Wilfred Cantwell Smith has shown, there is no word in classical Sanskrit for the concept and so "religion" does not appear in Hindu scriptures. There is also no word in Pali and so it also does not appear in Buddhist scriptures. There is no term for religion in Chinese or Japanese or Egyptian or in Native American languages (Smith 1962: ch. 2). There is not even a word for religion in the Hebrew Bible or in the Greek New Testament. One may speculate about whether Europeans in the seventeenth and eighteenth centuries developed the concept of "religion" because of the fragmentation of the Christian church in wake of the Reformation or because of the explosion of information about non-European cultures, but in any event it is only modern European Christians who generalized or abstracted from their own practices and developed the word "religion" as a term for sorting a certain kind of activity. Call this the social constructivist claim; agreeing with this claim suffices to make one a social constructionist.

Second, though other social constructionists have focused only on the emergence of "religion," one of the distinctive themes of Fitzgerald's work is his claim that the conceptual boundaries of religion cannot be drawn without simultaneously drawing the boundaries of non-religion. The concept of "religion" therefore emerged in conjunction with the concept of "the secular;" the two are flip sides of a single coin. This contribution to the debate is important, I judge, in that it lets us see how those who label others either as religious or

${ }^{2}$ Fitzgerald calls what he does "deconstruction" (2000a: 12, 245; 2007a: 8, 14; 2007c: 15, 97).

My enumeration of the parts of Fitzgerald's project is based on his own analysis (2007a: 6-7). Some of the next paragraph borrows from Schilbrack (2010). 
as lacking religion are simultaneously engaged in the construction of their own status. Call this the reflexive claim.

The third and most distinctive aspect of Fitzgerald's position is that he argues that the deployment of the new concept of "religion" — or more exactly, the deployment of the religion/secular pair of concepts-was central to the western attempts to justify colonialism. Call this the colonialist claim. In my judgment, only David Chidester (1996) focuses more on the use of the label of "religion" as a justification for the subjugation of non-western people. Notably, however, Chidester argues that European colonizers typically reserved the label "religion" for themselves and withheld it from Africans whereas Fitzgerald argues that the west has categorized itself as secular, rational, and progressive and used the concept of "religious" to label its other superstitious and backwards. These two approaches do not contradict each other, in my view, since both Fitzgerald and Chidester can be right and both may be needed to appreciate the variable uses of such a powerfully loaded term.

Thus, to enumerate the elements in Fitzgerald's approach, (1) the concept of "a religion" and of its pluralization "religions" is not recognized universally but is rather a product of European modernity, (2) this concept emerged in conjunction with its opposite, "the secular," and (3) the emergence of the religious/secular dichotomy served the justification of colonialism and is therefore a crucial part of modern Western ideology. I consider these social constructionist, reflexive, and colonialist claims the heart of Fitzgerald's project. Unfortunately, however, Fitzgerald also wants to argue that it is an implication of these ideas that (4) the concept of religion has no descriptive or analytical value. As he succinctly puts it: the word "religion" "picks out nothing and clarifies nothing" and should be abandoned. ${ }^{4} \mathrm{I}$ take it that it is this fourth claim that, in his own eyes, makes Fitzgerald's project deconstructive.

Now, it seems clear to me that the first three claims do not in fact imply the fourth. That is, one can agree that the concept of "religion" is historically emergent and ideologically implicated in the way that Fitzgerald argues, with deep theological and imperialistic roots, yet one can nevertheless hold that the term has analytic or descriptive value. The limits of the social construction position therefore turn on this claim that the concept of "religion" is descriptively and analytically useless. Why exactly should scholars deconstruct and abandon the concept? Fitzgerald gives several reasons for abandoning the concept of "religion." I turn to them now.

${ }^{4}$ Fitzgerald (1997: 93). Similarly, "the word has no genuine analytic work to do and its continued use merely contributes to the general illusion that it has a genuine referent.... [A]ny kind of analytic study of the word ['religion'] must be effectively abandoned" (1997: 14, 104). 


\section{Do Religions Exist?}

One reason Fitzgerald gives why the word "religion" describes nothing is that religion is "something that does not exist" (2007c: 7; cf. 47, 99). For the sake of tracking Fitzgerald's argument, we might call this claim "eliminativism" (cf. Webb). Eliminativism is the view that religions do not exist "out there" in the world. Fitzgerald argues that scholars should abandon the concept of "religion" as they come to see that religion is not a real entity but rather a rhetorical invention of the modern west. As he often says, that religion exists is a modern myth. Believing in religions is like believing in chimeras (2000a: 49, 168). But there is a non sequitur here: even if "religion" is a social construction, it does not follow that religion is mythical, chimerical, or does exist "out there" in the world. ${ }^{5}$ I now want to argue that eliminativism is not persuasive, and insofar as the deconstruction of "religion" is based on the idea that religion does not really exist, the deconstructive claim also fails to be persuasive.

It may sound disconcerting to hear that religion was not "discovered" but only "invented," and that the invention was merely "rhetorical," as Fitzgerald says. But it is less disconcerting if one keeps in mind that social facts are rhetorically invented by definition. A social fact like "there is a border between the two countries" is not based on some empirical or metaphysical reality. It is uncontroversially a social construction based on rhetoric. That there exist international borders is based on human agreement. That Obama is the American president is based on human agreement. That some pieces of paper are money is based on human agreement. Social facts are created by people for certain purposes, and their existence is sustained by convention, performance, and language and often by the power necessary to secure that rhetoric. ${ }^{6}$

The character of social realities gives those who want to use the concept of religion an obvious reductio against Fitzgerald. I agree that the concept of "religion" is a social construction, emerging only in the sixteenth and seventeenth centuries, along with politics and economics, as distinct domains of modern western culture. The concept would not exist without the historically specific and ideologically driven conditions under which it emerged. But if it followed from this socially constructed character of "religion" that there are no religions "out there," then the same could be said of politics and economics. ${ }^{7}$

\footnotetext{
5 I make this argument in more detail in Schilbrack, "Religions: Are There Any?" (2010). See also Stowers 2009.

6 There is a vibrant section of scholarship working on the ontology of social facts (see for example, John Searle, Margaret Gilbert, Fredrick Schmitt).

7 Fitzgerald of course recognizes that, like the idea of "religion," the idea of the "state" and the "economy" and other modern abstractions emerged in the Enlightenment: Bodin was the first,
} 
But this does not follow. There are religions out there just as much as there are borders between countries out there, there are touchdowns out there, and there are five dollar bills out there. The fact that "religion" is socially constructed does not imply that it does not refer to a thing (namely, a social thing) and therefore it does not imply that the term is analytically useless. Similarly, the fact that the concept of "religion" is co-emergent with the concept of the secular (Fitzgerald's point 2) and that it is a product of specific ideologically loaded events (Fitzgerald's point 3) do not lead us to an eliminativist conclusion. To deny that religions exist for those reasons would be analogous to saying that "there are no wives out there" because marriage is rhetorically invented, a wedding is an ideologically loaded event, and wives come into existence only in tandem with husbands.

So I conclude that even though the concept of "religion" is historically and ideologically conditioned, this by itself is not a sign that religions do not exist. And if they exist, then "religion" is a legitimate tool for the analysis and description of cultures.

\section{Can One Speak of Religions Outside the Modern West?}

Fitzgerald might support the idea that "religion" is descriptively and analytically useless with a different argument. He often points out that what is now called religion did not exist as a separate or distinct aspect of culture outside the modern west and that, therefore, to speak of "religions" outside the modern west is to impose a concept that is not in use in the cultures in question. Since "religion" is a social construction of the modern west, to employ the term elsewhere is to impose a foreign category. Now, this is surely right; that "religion" is typically a foreign category follows from the idea that it is a social construction. One might therefore make the claim that if a culture lacks the

\footnotetext{
he suggests, to think of the state as an abstraction from the person of the sovereign (2007c: 19). But Fitzgerald does not ever say that "states" do not exist or that it is descriptively and analytically useless to speak of "the economy." Why doesn't he? At one point, Fitzgerald says that some abstractions are "inherently useful" (2000a: 222). But no concepts are inherently useful; they are only useful given some purpose or another. I don't see how not to come to the conclusion that Fitzgerald has a double standard: though religion and politics are both rhetorical products of a colonialist Europe, he likes one and dislikes and therefore deconstructs the other. My proposal is that scholars can treat the concept of religion as Fitzgerald treats the concept of politics, that is, as a modern abstraction that has its descriptive and analytic uses. Fitzgerald's double standard is also in evidence when he writes that "cultures and societies exist in the world" (2000a: 243). (Fitzgerald responded to a version of this paper at the American Academy of Religion conference on November 8, 2009, and agreed that his view is that "religion" exists in the same way that "society" and "economy" exist.)
} 
concept of "religion," then it is inappropriate to use that concept when describing or analyzing it. Fitzgerald seems to make this claim: he often writes that to describe nonwestern cultures with the concept of "religion" is not only to employ a socially constructed concept, but is also necessarily to distort those cultures. ${ }^{8}$ About the assertion that the Pueblo had religion, for example, he says that "only the Pueblo people themselves can decide which Englishlanguage categories most truthfully represent their values and practices" (2007c: 92). ${ }^{9}$ More generally, he argues that it is a mistake for scholars to claim that they "understand the real meaning of people's institutions better than they do" (1997: 98). So it may be then that Fitzgerald is making a claim like the one proposed by Wilfred Cantwell Smith, who famously said that "no statement about a religion is valid unless it can be acknowledged by that religion's believers" (Smith 42). Or perhaps that this is the sense in which Fitzgerald claims that "religion" does not exist, holding, perhaps, that if a culture does not recognize a concept, then the entity to which that concept is meant to refer does not exist in that culture.

Neither of these two claims is a necessary part of the social constructionist program, but other social constructionists have used them. I advise my fellow social constructionists, however, not to go down these roads. Here are three reasons not to accept claims like these. In the first place, the idea that if a culture lacks the concept of "religion," then it is inappropriate to use that concept when describing or analyzing it insulates cultures not only from external critique but also from external interpretation. This claim blocks the academic study of cultures which requires concepts not used by those it studiesconcepts like "latent functions," "class," "gender," and so on. ${ }^{10}$ Similarly, in the second place, if it is true that when a culture does not recognize a concept, then the entity to which that concept is meant to refer does not exist in that culture, and so we cannot say that the Pueblo had a religion because they lack a word for it, then by the same reasoning we could not say that Pueblo had an economy or politics or gender. And lastly, to argue that something cannot exist in a culture unless that culture has a word for it opens one up to the kind of ridicule directed at Bruno Latour, the social constructionist who argued

\footnotetext{
${ }^{8}$ Ian Hacking has an illuminating discussion of the kinds of social construction positions and makes the distinction I am making here between (ii) and (iii), that is between the claim that $\mathrm{X}$ is socially constructed and the claim that $\mathrm{X}$ is bad (Hacking 1999: 19-21).

${ }_{9}^{9}$ Similarly, Fitzgerald points out that a distinction between natural and supernatural are not held by Native Americans (2007b: 211). This is the same point made by Emile Durkheim's The Elementary Forms of Religious Life, though Durkheim concludes that this implies that we need a definition that does not employ that Christian distinction, not that there are no religions.

${ }^{10}$ Robert Segal (2005) also makes this argument.
} 
that the pharaoh Ramses II could not have had tuberculosis since the very idea of tuberculosis is a modern western concept. ${ }^{11}$

My own label for claims like these that hold that one's world is limited to one's language is "linguistic determinism." Although to make this argument would take us too far afield, in the end, I judge that linguistic determinism is self-referentially incoherent. ${ }^{12}$ To avoid it, therefore, I recommend that one accept the idea that the modern western scholar who uses "religion" for premodern or nonwestern examples is imposing a foreign, etic concept. Imposing foreign concepts is simply part of what it means to interpret human behavior. To impose a concept that the people one studies do not recognize, however, is not to assume that one's concept captures the essence of things or the metaphysical nature of things (two phrases Fitzgerald uses regularly for the positions he rejects). It is merely to claim that the concept is fitting and that, for one's own purposes, it is interesting.

\section{Has the Term "Religion” Become Vacuous?}

Unfortunately for my proposal, one of the themes of Fitzgerald's work has been that it is not possible simply to impose the concept of "religion" however one might like. One of the problems he notes is that the term has been used so indiscriminately that it now refers to anything, and perhaps in the end this is why it is analytically useless. As he put it, "one finds in the published work of scholars working within religion departments the term 'religion' being used to refer to such diverse institutions as totems... Christmas cakes, nature, the value of hierarchy, vegetarianism, witchcraft, veneration of the Emperor, the Rights of man, supernatural technology possession, amulets, charms, the tea ceremony, ethics, ritual in general, The Imperial Rescript of Education, the motor show, salvation, Marxism, Maoism, Freudianism, marriage, gift exchange, and so on. There is not much within culture that has cannot be included as 'religion'" (1997: 92-3; cf. 105). As he says, many scholars today will use the label "religion" for any practice or institution that looks as though it is characterized by myths or rituals (2003: 211).

\footnotetext{
11 Latour says, before 1882, when the tuberculosis bacillus was discovered, "the bacillus had no real existence." For the ridicule, see Boghossian; Searle 2009.

12 Ted Slingerland calls linguistic determinism "word fetishism" and traces it to the (now largely discredited) Whorf-Sapir hypothesis in linguistics (Slingerland 2004: 5). One of the bestknown defenders of the claim that "Our idea of what belongs to the realm of reality is given for us in the language we use... The world is for us what is presented through those concepts" is Peter Winch; for a critical discussion of Winch's position, see Schilbrack 2009.
} 
Fitzgerald illustrates how a term can be emptied of its distinctiveness with his analysis of the concept of "religious experience" (2000b). He argues that that the category of "religious experience," like that of "religion" generally, has become "so wide that it has little analytic value" (2000b: 125). The term is "radically open-ended, [and] sliding" in its usage (2000b: 125). Originally the term "religious experience" was used to refer to ecstatic, "peak" experiences epitomized by personal encounter with the God of the Bible. Call this use of the term to refer to extraordinary theistic experiences: sense A. The label was later used to refer to a broader range of experiences, experiences that are quotidian and usual, such as experiencing the natural world as Creation, as in the saying, "Look at the day the Lord has made." Call this use of the term to refer to more ordinary theistic experiences: sense B. And then the term has been even further "extended" and "stretched" and "diluted" (2000b: 126, 129, 137) to include nontheistic experiences. In this usage, one employs the label for non-theistic examples like the Buddha's enlightenment or for Advaita awareness of non-duality, and eventually even to any experiences of ultimacy or sacredness. Call this non-theistic use of the term: sense C.

Now, this accusation that the term's meaning has been stretched might be understood in two ways: the first is that these three kinds of references are so disparate and so multiple, that the term has lost its meaning. We might say: the problem is that scholars are using a term to mean $\mathrm{A}$, and $\mathrm{B}$, and $\mathrm{C}$, and so the meaning of the term, as Fitzgerald says, slides. A different concern is that the term is now used to refer to such an inclusive set of references that it is conceptually incoherent. We might say: the problem is that scholars now use the term "religion" to mean $\mathrm{C}$, but $\mathrm{C}$ is so broad that the term is now effectively useless. I am not sure whether Fitzgerald distinguishes these two problems, so let's consider them in turn.

If the criticism of the concept of "religion" is that it now has multiple, incompatible senses- $\mathrm{A}$ and $\mathrm{B}$ and $\mathrm{C}$ - then that argument is weak. This argument only works if a scholar uses "religious experience" to refer to theistic peak experiences, and also everyday experiences, and also nontheistic experiences. But it does not mean all three of these things to any one theorist; it only has multiple meanings if one collapses all the different users of the term together. But that is unfair. Consider this analogy: if I use the term "brother" (or, to make the analogy, "fraternal experience") to refer to a forty-three year old man named Scott who used to live with me in Florida but my son Alex uses it to refer to an fourteen year-old boy named Elijah who lives with him in North Carolina, the term is not radically open-ended or sliding. This usage is not incoherent or vacuous. Similarly, if some theorists use "religious experience" only to refer to theistic peak experiences, and work hard to draw conceptual boundaries around their use of the term, it is no criticism of those 
theorists that other scholars use the term in other ways. Thus the first way of reading Fitzgerald's critique only seems plausible if one indiscriminately combines the views of people who disagree with each other.

The second criticism - that the term "religion" has been extended to mean so many different things that it has been diluted to the point that it is analytically useless - is more interesting. Clearly, Fitzgerald is right that these days "religion" or "religious experience" does get used to refer not only to theistic experiences and not only to experiences who find their home in Buddhism or Hinduism or other traditions widely recognized as religious, but also to many allegedly secular experiences that are said to be ultimate. Two recent examples of this use of the term "religion" that I recently read and liked are these: Samuel Snyder uses the language of religious experience to understand those anglers who speak about their wet hours of fly-fishing as meditative times, of rivers as sacred places, and of fishing as providing a sense of connection to nature and motivating them to environmental conservation (Snyder 2007). And Ira Chernus analyzes the neoconservative political movement, especially in its pursuit of the invasion of Iraq as a puritanical and Manichean religious experience. Chernus quotes Irving Kristol, a guiding spirit of the neo-con movement, who explained their political views this way: "It is crucial to all human beings at all times that they encounter a world that possesses transcendent meaning, a world in which the human experience makes sense" (Chernus 2008). In these examples of actions as disparate as fly-fishing and the War on Terror, the definition of religion at work is a functional one: a religion is whatever gives ultimate purpose to one's life.

But if these examples reflect the diluted use of "religion," then Fitzgerald's complaint about the vacuity of the term is not really a problem with "religion" as such, but rather only with functional definitions of it. In his well-known discussion of definitions of religion, Melford Spiro makes the same observation: with "functional definitions of religion... it is virtually impossible to set any substantive boundary to religion and, thus, to distinguish it from other sociocultural phenomena. Social solidarity, anxiety reduction, confidence in unpredictable situations, and the like, are functions which may be served by any or all cultural phenomena-Communism and Catholicism, monotheism and monogamy, images and imperialism - and unless religion is defined substantively, it would be impossible to delineate its boundaries" (1966: 89-90). But if functional definitions of religion make empirical studies difficult, the conclusion is not that religious are "nonexistent objects"! The conclusion is: don't use a functional definition of religion.

It seems easy to avoid functional definitions of religion. Fitzgerald mocks the all-inclusive usage of the term, asking: Would being educated by the Japanese Ministry of Education count as a religious experience? (2000: 194-7; 
cf. 1997: 102). But let's say that one could describe a Japanese education so that it connected to one's deepest existential concerns. The proper question is not whether this "is" a religion, but rather: according to what definition of religion would this count as a religion? To the sociologist Milton Yinger (1975), who defines religion functionally as a way that a group of people responds to what it sees as the ultimate problems of life, an educational experience that gives one a sense of purpose and identity might well count as religious experience. But to the anthropologist Robin Horton (1993), who defines religion as dependent social relations with non-human alters, educational experiences are clearly not religious because they do not involve spiritual beings. So one solution to Fitzgerald's critique would simply be to avoid functional definitions of religion and instead to use a substantive definition of "religion," a definition that lets one distinguish temples from post offices.

\section{Does Religion Pervade the Secular?}

To put the point graphically, however, one of the main themes of Fitzgerald's work is that temples cannot be distinguished from post offices. That is, one of the reasons he gives for the conclusion that "religion" identifies nothing is that religion and the secular cannot be distinguished. What is religious and what is secular cannot be even conceptually pulled apart. What is his argument?

Fitzgerald may well be right that, outside the modern west, what moderns call "religion" permeated the culture. I have been defending the idea that even if this is the case, one can nevertheless speak of "religion" as a distinct aspect of a culture, and that the scholar can do so even when the culture in question does not distinguish them. But for the sake of argument, let me concede that, outside the modern west, "religion" was, as Fitzgerald claims, identical to culture. Nevertheless, if in the modern west, "religion" is not identical to culture, then religion does exist at least here and now as a distinct domain. In fact, given the near-global spread of modern western ideas, religion has become a distinct aspect of culture almost everywhere. To make his case that "religion" is descriptively and analytically useless, therefore, Fitzgerald needs to show that religion is identical to culture even in the modern west.

Now, one might think that if Fitzgerald has said that scholars should respect the self-understanding of those we study, then this argument won't get off the ground. If modern western people think that they distinguish between the religious and the non-religious, then he should not contradict them. To do so is to violate his own rule that the scholar should not claim to "understand the real meaning of people's institutions better than they do" (1997: 98). But he 
does it anyway. One might also think that if Fitzgerald argues that even the modern so-called secular world is religious, and so he argues that religion exists both in the premodern and in the postmodern world, both outside the west and in the west, then he is arguing that religion is a cultural universal. And he has said that this is what his opponents do and what he opposes (e.g., 2007c: 4-5). Still, he does it anyway.

So, what is his argument that the modern secular west is really religious? "[I]t seems obvious," Fitzgerald writes, "that there are many beliefs and practices in our own western cultures that might normally be categorized as 'secular' but that could equally be called religious" (2007a: 3). One of Fitzgerald's examples of a secular "god" is money. As symbolized on the cover photo of Discourse on Civility and Barbarity, the statue of the Bull of Wall Street is a symbol of "mystical power" (2007c: x). Fitzgerald calls it a fetish: "pilgrims [to Wall Street] gingerly touch and stroke its magnificent surfaces, as though some extraordinary but potentially dangerous energy might emanate from it and liberate them in a spasm of self-realization from the sin of poverty" (2007c: $x$ ). Economics has become a "virtual theology" of liberal capitalism and politicians are its "priests," inspired by "blind faith" in their "god" (2007c: ix-x). A second example of the way that in Fitzgerald's eyes religion pervades the modern secular world is the reverence the modern people have for the nation (2007c: 260). The language of American triumphantalism in particular, Fitzgerald says, "tends toward the visionary and the prophetic, and the American sense of liberty and destiny can sound soteriological and even apocalyptic" (2007c: 292). In the United States, the events of the American Revolution are seen as "sacred mythology," its heroes as "saints of the modern sacred," the Constitution is "a sacred document and it legitimates sacred rights" (2007c: $292,293,296)$. They are sacred even if they are not supernatural because they evoke feelings of awe (2007c: 296). "The idea of the sacred has never been confined to church matters" (2007c: 296). That is, even though moderns want to separate religion from politics, they cannot, because the myths and the rituals that evoke feelings of awe and the experience of the presence of the sacred pervade society in the modern world, just as they did in the premodern world. "[T] he language of sacrality has never been confined in the English language to religion in the narrow modern sense of a privatised, nonpolitical faith in a future life or an unseen world, but it has also been strongly connected to the values and aspirations of the state, of government, of civil society, and of what has been constructed as 'the secular' in modernity" (2007c: 298).

It is striking that Fitzgerald just declares that it is "obvious" that these things are religious. Also striking is how much of his case depends on the phenomenologists of religion and their discussion of feelings of awe and the sacred, an 
approach that Fitzgerald scorns as covertly theological. ${ }^{13}$ Many in the study of religion will therefore find Fitzgerald's examples of the way that modern allegedly secular events and people function as religion completely unobjectionable, and this is precisely because those scholars adopt a definition of religion in which religion is whatever serves one's ultimate concern. The claim that capital and the nation do this is not new.

But the shape of Fitzgerald's overall argument is now clearer. His goal is to argue that it is not possible to conceptually distinguish religion from the nonreligious. The two are identical and this is why "religion" is analytically and descriptively useless. One might see his argument as having two steps: First, against substantive definitions, Fitzgerald argues that the attempt to distinguish religion as interaction with superhuman beings fails to see that such beliefs and practices cannot be understood independent of the allegedly nonreligious parts of the culture. As he says, what some have tried to hive off as "religion" "cannot be understood in isolation from a whole range of other ritual institutions in the context of which they form a symbolic system" (1997: 92). Interaction with superhuman beings "cannot be separated out as a genuinely distinct areas [sic] of research separated from the economic, political, and more broadly ritual aspects" (1997: 103). To use this definition of religion is to "tear one aspect of a complex cultural situation out of context" (1997: 103). These are only assertions and do not show why temples cannot be understood without reference to post offices. But if I understand his argument, Fitzgerald's assertions about the failure of substantive definitions to distinguish religion from non-religion is based on his (unacknowledged) shift to a functional definition of religion.

In the second step of his argument, Fitzgerald argues that functional understandings of "religion" broaden the concept so widely that it becomes indistinguishable from culture. "The word 'religion' is now used to refer to so many different things that it has become virtually synonymous with 'culture' and 'society' in the broadest senses. There is virtually no situation where one could say that any collectively valued idea, act, experience, custom, status, story, place, or person is not subsumed under the category religion in religious studies or other humanities texts" (2000a: 222). In this way, functional definitions

13 Though Fitzgerald assimilates religion to the sacred and to feelings of awe for his own argument, he criticizes this approach when phenomenologists of religion use it: "writers such as Rudolf Otto and Mircea Eliade have turned what is basically a theological/metaphysical assumption into a theory of religion" (1997: 92). Moreover, the view that even the nonreligious have a religion in the sense that something serves for them as an ultimate concern is typically identified with Paul Tillich's liberal and ecumenical theology. Fitzgerald criticizes this approach harshly as a muddle and an inappropriate theological move (1997: 91). It is hard not to read Fitzgerald as again employing a double standard. 
also fail to distinguish religion from non-religion and so " 'religion' dissolves or ought to dissolve without remainder into ideology or culture understood as institutionalized values and symbolic systems" (2000a: 17).

I have argued that even if it is not possible to separate religion and culture, it is possible to distinguish them. But Fitzgerald argues that precisely this is not possible. Religion and culture are indistinguishable. If Fitzgerald is right about this, then he is right that "religion" is not analytically useful. And I have agreed with him that the two concepts of religion and secular are two sides of a single coin. Nevertheless, I believe that there is a conceptual oversight in this argument and it is this: Fitzgerald does not distinguish between the concept of distinguishing and the concept of separating, but he should. ${ }^{14}$ Let me explain.

Sometimes two allegedly different entities can be neither distinguished nor separated: it turns out that they are actually identical. A famous philosophical example of this is the planet Venus and the Morning Star. Sometimes, however, two entities can be both distinguished and separated: the two are completely different. For example, one can distinguish between the boxer in the red shorts and the boxer in the blue shorts, and sometimes they also need to be separated. As we have seen, Fitzgerald speaks in this first way about religion and culture. He is arguing that it is incorrect to assume that religion is separate and distinct from culture generally. Now, if "distinguishing" and "separating" mean the same thing, then any two allegedly different entities are either both distinct and separate or neither distinct nor separate; complete identity and complete difference are the only two possibilities. But "distinct" and "separate" do not mean the same thing, since sometimes two things cannot be separated, but they can still be distinguished.

An example may make this idea clearer. Imagine a man who is both a father and a husband. The person qua father and the person qua husband cannot be separated. There are not really two people here, and the one person does not have separable father parts or husband parts (John Wayne Bobbitt notwithstanding). The two concepts and roles and aspects of his personality may be inter-connected and may permeate his life. Many of the activities in which he engages may be equally related to being both a husband and a father. Nevertheless, in the analysis and description of how this individual is like or unlike other individuals, one can focus on the father aspect while leaving the husband

\footnotetext{
${ }^{14}$ Fitzgerald makes the claim that religion and culture cannot be distinguished or separated dozens of times throughout his works. Sometimes Fitzgerald says that the two cannot be separated, the view I am advocating. But sometimes he says that they cannot be distinguished. And sometimes he says that they cannot be separated or distinguished.
} 
aspect in the background, or vice versa. For instance, one can say that he is a good father but not a good husband, or the reverse.

My proposal is that just as one can distinguish between a person as husband and father, one can speak analogously of a person qua religious or qua political. One can do the same for a monument, for a ritual, or for any other aspect of a culture. ${ }^{15}$ Fitzgerald is correct that there are premodern and non-western cases in which the two cannot be separated. A king, for example, may be both a political and a religious authority, and these two parts cannot be separated. Fitzgerald holds that if they cannot be separated, then they cannot be distinguished. But if I am right that to separate is not the same as to distinguish, then this is a non sequitur. That is, those of us in the modern west who do distinguish between religion and politics can distinguish between the king qua religious authority (for example, insofar as he represents the divine) and the king qua political authority (for example, insofar as he governs) even if they are not so distinguished by the culture in question. These two aspects of the cultural entity may be as inter-connected and blended as the roles of husband and father, and they cannot be physically separated, but they can be conceptually distinguished.

\section{What Is Religion?}

I have argued that in his argument that religion cannot be distinguished from culture, Fitzgerald uses a functional definition of religion that he borrows from the phenomenologists and theologians he critiques. I have trouble not seeing this as double standard, but perhaps it is "skillful means." For when he is being true to his deconstructive, dissolving approach, Fitzgerald rejects all such attempts to define "religion." He argues that we should drop the discussion of what religion is and replace "religion" with terms that give us greater analytic specificity: ritual, politics and soteriology (Fitzgerald 1994).

With this recommendation, Fitzgerald resembles those who say that religion is a family resemblance concept: it has no essence but is constituted by a set of features, none of which is essential. ${ }^{16}$ However, Fitzgerald says that his approach is not really itself a family resemblance treatment of religion, because

\footnotetext{
${ }^{15}$ Jeppe Jensen (who, like me, argues that the term "religion" can be rehabilitated as a cultural taxon) makes exactly this point, arguing that religion can be distinguished from the rest of a culture even if it cannot be separated from culture and is always positioned within culture (1993: 121), and Fitzgerald responds, apparently without comprehending this point, "I do not agree that religion can be usefully separated from culture" (1997: 101).

${ }^{16}$ If Fitzgerald's approach is a kind of family resemblance treatment of religion, then it defines religion in terms of three features whereas Ninian Smart, for example, famously has seven, William Alston has nine, and Benson Saler has fourteen (see Smart, Alston, Saler). In this respect,
} 
his is not an attempt to define religion at all. Instead he says that he is dissolving the concept, breaking it down without remainder into more basic elements.

But this strategy is confused. For clearly there is a difference between each of these elements and the whole, and we need a word for the whole. That is, there are institutions in at least some cultures that combine ritual, politics and soteriology, and we need some label for those. What do we label those multifaceted aspects of a culture that bring together the ritualized, the political, and the salvific? (If we use Fitzgerald's suggested term, and take the beginning of the word "ritual" — "ri" — the middle of the middle word politics - "li" and the end of the last word, soteriology — "gy" - to create new term for this aspect of culture, then the study of religion would be replaced by the study of "religy." But this is hardly a radical shift.)

Moreover, why Fitzgerald argues that the concept of "religion" is implicitly theological and carries the conceptual baggage of Christian Truth, but that his own use of the term "soteriology" is permissible is beyond me. Fitzgerald's use of the concept of soteriology seems to be another example of a double standard in which he blasts his opponents for what he allows himself. He says that those who use the term "religion" do not realize that the term is "thoroughly imbued with Judaeo-Christian monotheistic associations and World Religions Ecumenism" (1997: 95). Those who use the term "transcendent" do not realize that it is "necessarily" problematic, for it has "been so thoroughly penetrated by western theological and ontological associations that it is likely to import disjunctive meanings into an analysis, either unwittingly or deliberately for ecumenical purposes" (1997: 94). One might think that the same worries about an obviously Christian theological word as soteriology would raise the same concerns and even the same questions about whether soteriology is a real "thing." But Fitzgerald demurs: "soteriologies clearly exist," he asserts, for example, in monastic Buddhism (1997: 93).

Can the term "religion" not be redeemed? One of the reasons that Fitzgerald seeks to abandon the concept of "religion" is that, as he often says, the modern western construction of "religion" is the construction of religion as private. ${ }^{17}$ And he is right that the notion that religion is a matter of private belief or experience is widely assumed in the modern west. But this view is also often opposed by those in religious studies. Many, many scholars work to theorize public religion. One well-known example is Jose Casanova's book,

\footnotetext{
Fitzgerald's approach does not give us more analytic specificity than other options in religious studies, but less.

17 Thus: "The general theoretical concern was with the ideological function of the privatization of religion and its separation from politics and other forms of secular discourse, with especial reference to the dominance of Western capitalism and the colonial relationship" (2007a: 5).
} 
Public Religion in the Modern World (1994). Another is Mark Juergensmeyer who describes the global rise of religious nationalism (1994). And a third is Bruce Lincoln, who develops the idea of "maximal religion" that permeates a culture (2003: ch. 4). The truth is that public, political religion has been recognized by every historian who has spoken of the divine right of kings, the Biblical legitimation of slavery, the apotheosis of pharaohs, or whether the emperor has lost the mandate of heaven. The claim that the field of religious studies assumes that religion is private is therefore an exaggeration at best.

Strangely, Fitzgerald aims some of his harshest criticisms at precisely the scholars like those three just mentioned who speak of religion and politics influencing each other, as blending and overlapping in their motives and objects. In my judgment, one of the most insightful theorists of the ideological uses of religion - that is, of the ideological uses of religious discourses, practices, and institutions_-is Bruce Lincoln. ${ }^{18}$ One part of Lincoln's approach is to make people aware of the shift in the meaning of the term "religion" in modernity. As I mentioned above, Lincoln signals this by distinguishing between what he calls religion in a maximalist sense in which religion permeates a culture and religion in a minimalist sense in which religion is limited to the private sphere. Fitzgerald criticizes Lincoln and others, however, arguing that even with the recognition that there are public and political "maximalist" religions, these scholars still assume that religion is something that can be defined or put into a typology. They assume that there is something that can be analyzed or distinguished as religion.

In his own work, however, Fitzgerald recommends the following terms: "encompassing religion" and "privatized religion" (2007b). These are, he says, two "kind[s] of religion" (211). Fitzgerald then applies his concept to cultures that did not have this concept. At the end of this essay, my point is not that by creating a definition and a typology of religion Fitzgerald is here contradicting himself (though it seems to me that he is), nor that Fitzgerald's ideas repeat Lincoln's (though it seems to me that they do). My point is that insofar as Fitzgerald's concept of "encompassing religion" illuminates the pervasiveness of religion in premodern English villages or in Japanese culture, Fitzgerald shows that the concept of "religion" is analytically and descriptively useful. $\mathrm{He}$

\footnotetext{
${ }^{18}$ It is worth noting in passing that Fitzgerald misreads Lincoln. Lincoln proposes that "religion" be defined as discourse, practices, community, and institution "whose concerns transcend the human, temporal, and contingent, and that claims for itself a similarly transcendent status" (2003: 5). He thereby gives us one way of distinguishing a temple from a post office. Overlooking what makes religion distinctive for Lincoln, Fitzgerald asks: "If discourse, practice, community and institution are what constitute the core components of the nature of religion (its essence), how does religion differ from secular history, or from secular politics, or from secular anything you like? Do they not all have discourse, practice, community and institution?" (2007a: 4-5).
} 
shows that for the concept to be analytically useful, one has to take the modern, minimalist, privatized understanding of the concept and extend or stretch or dilute it so that one recognizes that religion also has a maximalist or encompassing form. Given these conceptual distinctions, there is a spectrum of ways that religion can exist. Religion is a general type of which there are different kinds. Once one has done this, one can then impose the concept of religion on those who have no such concept, just as Fitzgerald himself does.

\section{The Social Construction of Religion and the Scholar}

Fitzgerald's work contributes to the increased reflexivity of scholars of religion. By this I mean that he helps scholars see how the use of certain concepts to describe others simultaneously constructs one's own status. It is therefore appropriate to end this essay with attention to the reflexive question about the normative status of the scholars of religion themselves.

As we have seen, Fitzgerald argues that outside the modern west, what is now called "religion" permeated the culture. One could not separate, for example, the king as a religious figure from the king as a political figure. There was no separate domain of "the non-religious" or "the secular." In the modern west, however, beginning especially in the seventeenth century there has been an attempt to separate the two. But Fitzgerald argues that there has been and can be no real separation. In his own words, Fitzgerald rejects "the idea of a world divided between religion and non-religion, understood as neutrality towards 'religion' and therefore as essentially distinct from 'religion'” (2007a: 7).

What does this imply for the self-understanding of scholars of religion? One way to read Fitzgerald is as saying that scholars of religion cannot see themselves as not themselves religious. They cannot be secular and they cannot be religiously neutral. He seems to be arguing that it is impossible for scholars of religion to carve out a domain distinct from religion where they can do their own thinking. As Fitzgerald puts it, "All paradigms rest on metaphysical assumptions including my own" (1997: 97). "[The] issues of how we should look at the world and how we should interpret institutions take place within a framework of metaphysical assumptions that always need to be made explicit" (1997: 97). And since all scholars of culture operate with normative assumptions, "we are not different from theologians" (1997: 97). ${ }^{19}$

If this is what Fitzgerald means, then I want to clarify and bolster this argument. It may be that what Fitzgerald means here is that all thinking is not only

\footnotetext{
${ }_{19}$ This may be why some theologians like the Paul Griffiths (2000) are enthusiastic about Fitzgerald's brand of deconstruction.
} 
theory-laden but also value-laden. I would add this claim to my master list of what I take to be the central theses of his position, that is: (5) no form of thinking is normatively neutral. Norms are in this sense an ineliminable part of culture as such. As Charles Taylor has argued, human beings can operate only within the context of a normative space defined by a framework of empirically unverifiable beliefs (1990). Human beings are necessarily moral animals (see Christian Smith). If every social order is infused with some values or other, and all human purposes, actions, and institutions are informed by norms, then there cannot be a part that is not based on norms or that is valuefree. Fitzgerald therefore is right that if a culture were to separate itself into two coherent parts, they could not be the part that expresses values and the part that is value-free. And if a culture were to label the parts that express values "religious" and the parts that are allegedly objective and value-free and neutral "secular," then this would not change the fact that the culture's values permeate both sides of that divide. In fact, the making of a fact/value distinction would itself be an expression of the values of the culture. Any such separation would be confused and merely rhetorical.

But this claim that no thinking is normatively neutral conflicts with other social constructionist approaches to "religion." Like Fitzgerald, Donald Weibe and Russell McCutcheon have also argued that "religion" is a social construction and that the creation of the field of religious studies serves theological and political interests (Weibe 2000, McCutcheon 2001). Like Fitzgerald, they show how "religion" has been constructed as a private reality, irreducible to scientific explanation and autonomous. Like Fitzgerald, they want to deconstruct this concept of "religion." However, they argue that if the study of religion is going to be appropriate for the secular academy, then precisely what it must do is to carve out a domain distinct from religion where they can do their own thinking, to separate the teaching about religion from the teaching of religion. Their goal is to exclude theology as a way of thinking from the academy, so that the academy will be wholly naturalistic. But if Fitzgerald is right, then it is not possible to separate some naturalistic or scientific or otherwise nontheological place where scholars can think about religion, or about anything else. Fitzgerald sees the allegedly superior nonreligious discourse on religion and religions as part of a quintessentially modernist ideology (2007c: 31). To put this point antagonistically: it seems that if Fitzgerald deconstructive project succeeds, then McCutcheon's deconstructive project fails. ${ }^{20}$

\footnotetext{
${ }^{20}$ It may be worth noting that McCutcheon also disagrees with Fitzgerald's claims that the term "religion" is analytically useless and that it ought not be applied to cultures that do not use it. On those two points, my understanding of the implications of social construction agrees with McCutcheon's.
} 
McCutcheon has told me that this is a misreading of Fitzgerald. And McCutcheon may be right since-despite the fact that one of the central theses of Fitzgerald's project is the claim that religious thinking cannot be separated from non-religious thinking-immediately after he says that scholars of religion are not different from theologians, he says that theology and religious studies "ought to be two logically separate levels of intellectual activity" (1997: 97). And he says that the way to separate them is by abandoning the theologically loaded term "religion.” So apparently in Fitzgerald's eyes theological and nontheological ways of thinking actually can be separated.

How one should interpret Fitzgerald seems very unclear. But the question remains: is it possible to separate or distinguish a way of thinking that is normatively neutral, or does all thinking imply norms?

My own answer to this question can only be stated baldly here, but it was suggested in my previous distinction between the concept of separating and the concept of distinguishing. I hold that it is not possible to separate some realm of thinking that is neutral or value-free. In this sense, the theorizing about religion done by secular academics shares with theology, as it shares with all forms of thought, an at least implicit sense of what is good and true. All thinking is normative or value-laden, and there is no privileged neutral view. On the other hand, I also hold that it possible to distinguish those forms of thinking that make it their explicit task to uncover and critically reflect on their fundamental normative assumptions from those forms of thinking that do not have this as their explicit task. In this respect, although all branches of the academic study of religion assume and imply norms, not all branches take it as their central task to state explicitly or to defend their value commitments.

In the end, it may be that this brief statement only restates the view that Fitzgerald was seeking to articulate. Reflexivity about the concepts and values that inform the study of religions is a crucial but unfinished discussion. But my own view is that it leads to a recognition that "religion" is a socially contracted concept, analytically and descriptively useful for some purposes, but that it cannot be studied without at least certain norms held at least implicitly by the scholar.

\section{References}

Alston, William P. (1967). "Religion.” In Paul Edwards, ed. The Encyclopedia of Philosophy, Vol. 7. New York: Macmillan Publishing Co.

Balagangadhara, S. N. (1994). 'The Heathen in His Blindness...': Asia, the West and the Dynamic of Religion. Leiden: Brill.

Boghossian, Paul A. (2006). Fear of Knowledge: Against Relativism and Contructivism. Oxford: Clarendon Press. 
Casanova, José (1994). Public Religions in the Modern World. Chicago: The University of Chicago Press.

Chernus, Ira (2008). "The War in Iraq and the Academic Study of Religion." Journal of the American Academy of Religion 76:4 (December): 844-873.

Chidester, David (1996). Savage Systems: Colonialism and Comparative Religion in Southern Africa. Charlottesville: The University Press of Virginia.

Dubuisson, Daniel (2003). The Western Construction of Religion: Myths, Knowledge, and Ideology. Baltimore, MD: The John Hopkins University Press.

Fitzgerald, Timothy (1994). "Ritual, Politics, and Soteriology in Ambedkar Buddhism." Indian Journal of Buddhist Studies 5, pp. 25-44.

- (1997). "A Critique of 'Religion' as a Cross-Cultural Category." Method and Theory in the Study of Religion 9:2, pp. 91-110.

- (2000a). The Ideology of Religious Studies. New York: Oxford University Press.

(2000b). "Experience." In Willi Braun and Russell McCutcheon, eds, Guide to the Study of Religion. London: Cassell.

- (2003). "Playing Language Games and Performing Rituals: Religious Studies as Ideological State Apparatus." Method and Theory in the Study of Religion 15:3.

- (2007a). "Introduction." In Timothy Fitzgerald, ed., Religion and the Secular: Historical and Colonial Formations. London: Equinox.

(2007b). "Encompassing Religion, Privatized Religions, and the Invention of Modern Politics." In Timothy Fitzgerald, ed., Religion and the Secular: Historical and Colonial Formations. London: Equinox.

(2007c). Discourse on Civility and Barbarity. New York: Oxford University Press.

Gilbert, Margaret (1992). On Social Facts. Princeton: Princeton University Press.

Griffiths, Paul J. (2000). “The Very Idea of Religion.” First Things 103 (May): 30-5.

Horton, Robin (1993). "A Definition of Religion, and its Uses." In his Patterns of Thought in Africa and the West. Cambridge University Press.

Jensen, Jeppe (1993). "Is a Phenomenology of Religion Possible? On the Ideas of a Human and Social Science of Religion." Method \& Theory in the Study of Religion 5:1 (1993): 109-133.

Juergensmeyer, Mark (1994). The New Cold War? Religious Nationalism Confronts the Secular State. Berkeley: University of California Press.

Lincoln, Bruce (2003). Holy Terrors: Thinking about Religion after September 11. Chicago: The University of Chicago Press.

McCutcheon, Russell T. (2001). Critics not Caretakers: Redescribing the Public Study of Religion. Albany: State University of New York Press.

Saler, Benson (1993). Conceptualizing Religion: Immanent Anthropologists, Transcendent natives, Unbounded Categories. Leiden: E. J. Brill.

Schilbrack, Kevin (2009). "Rationality, Relativism, and Religion: A Reinterpretation of Peter Winch." Sophia: International Journal for Philosophy of Religion, Metaphysical Theology and Ethics. 48: 4 (November 2009): 399-413.

_ (2010). "Religions: Are There Any?" Journal of the American Academy of Religion. 78:4 (December 2010): 1112-38.

Schmitt, Fredrick, ed. (2003). Socializing Metaphysics: The Nature of Social Reality. Lanham, MD: Rowman and Littlefield.

Searle, John R. (1995). The Construction of Social Reality. New York: The Free Press. (2009). "Why Should You Believe It?" The New York Review of Books 56:14 (Sept. 4), 88-92.

Segal, Robert (2005). "Classification and Comparison in the Study of Religion: The Work of Jonathan Z. Smith." Journal of the American Academy of Religion 73:4 (December): 11751188. 
Slingerland, Edward (2004). "Conceptual Metaphor Theory as Methodology for Comparative Religion." Journal of the American Academy of Religion 72:1 (March): 1-31.

Smart, Ninian (1996). Dimensions of the Sacred: An Anatomy of the World's Beliefs. Berkeley: University of California Press.

Smith, Christian (2003). Moral, Believing Animals: Human Personhood and Culture. Oxford University Press.

Smith, Jonathan Z. (1998). "Religion, Religions, Religious." In Mark C. Taylor, ed., Critical Terms for Religious Studies. Chicago: The University of Chicago Press.

Smith, Wilfred Cantwell (1959). "Comparative Religion: Whither—and Why?” In Mircea Eliade and Joseph M. Kitagawa, eds, The History of Religions: Essays in Methodology. Chicago: University of Chicago Press.

(1962). The Meaning and End of Religion. Minneapolis: Fortress.

Snyder, Samuel (2007). "New Streams of Religion: Fly Fishing as a Lived, Religion of Nature." Journal of the American Academy of Religion 75:4 (December): 896-922.

Stowers, Stanley (2009). "The Ontology of Religion." In Willi Braun and Russell T. McCutcheon, eds, Introducing Religion: Essays in Honor of Jonathan Z. Smith. London: Equinox.

Taylor, Charles (1990). Sources of the Self. Cambridge: Cambridge University Press.

Weibe, Donald (2000). The Politics of Religious Studies. Palgrave Macmillan.

Webb, Mark Owen (2009). "An Eliminativist Theory of Religion." Sophia 48: 1 (February): $35-42$.

Yinger, J. Milton (1970). The Scientific Study of Religion. New York: Macmillan. 